Provided for non-commercial research and education use. Not for reproduction, distribution or commercial use.

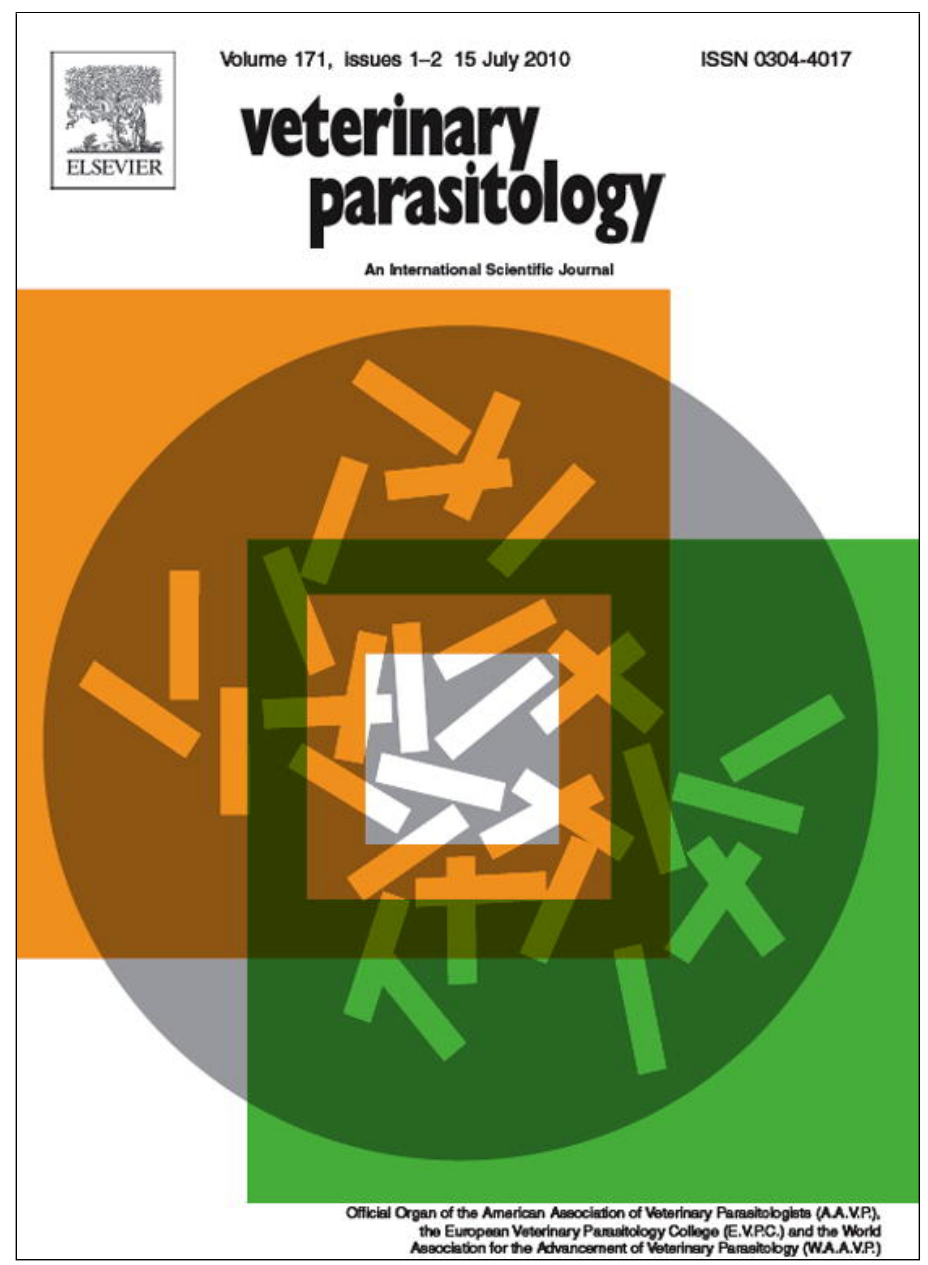

This article appeared in a journal published by Elsevier. The attached copy is furnished to the author for internal non-commercial research and education use, including for instruction at the authors institution and sharing with colleagues.

Other uses, including reproduction and distribution, or selling or licensing copies, or posting to personal, institutional or third party websites are prohibited.

In most cases authors are permitted to post their version of the article (e.g. in Word or Tex form) to their personal website or institutional repository. Authors requiring further information regarding Elsevier's archiving and manuscript policies are encouraged to visit:

http://www.elsevier.com/copyright 


\title{
Impact of amoeba and scuticociliatidia infections on the aquaculture European sea bass (Dicentrarchus labrax L.) in Portugal
}

\author{
Maria João Santos ${ }^{\mathrm{a}, \mathrm{b}, *}$, Francisca Cavaleiro ${ }^{\mathrm{a}, \mathrm{b}}$, Pamela Campos ${ }^{\mathrm{a}}$, André Sousa ${ }^{\mathrm{a}}$, \\ Filipa Teixeira ${ }^{a}$, Marta Martins ${ }^{\mathrm{a}}$ \\ a Departamento de Biologia, Faculdade de Ciências, Universidade do Porto, Rua do Campo Alegre, s/n, FC4, 4169-007 Porto, Portugal \\ b CIMAR Laboratório Associado - CIIMAR, Centro Interdisciplinar de Investigação Marinha e Ambiental, Universidade do Porto, Rua dos Bragas, 289, \\ 4050-123 Porto, Portugal
}

\section{A R T I C L E I N F O}

\section{Article history:}

Received 13 July 2009

Received in revised form 3 March 2010

Accepted 11 March 2010

\section{Keywords:}

Amoeba

Aquaculture

European sea bass

Dicentrarchus labrax

Scuticociliatidia

\begin{abstract}
A B S T R A C T
In this work, a survey of sea bass, Dicentrarchus labrax, for amoebae and scuticociliatidia infections was carried out to evaluate their effects on the aquaculture of this fish species. The study was conducted in two different fish farms, one using seawater and the other brackish water.

Infection with parasitic amoebae was found to be fairly high (prevalence: 43-73\%), being more frequent in sea bass from the brackish water system. Although it was never found to cause outbreaks of disease or mortality in the surveyed fish, amoebic gill disease (AGD) histopathological signs, i.e., hyperplasia, secondary lamellae fusion and cavity formation (interlamellar vesicles), were observed in fish manifesting no macroscopic lesions. Furthermore, some evidence was found that amoebae affects the fish's general state of health and growth rate. These results indicate that cautious and detailed surveys to detect this sort of infection, and thus carefully plan its control, are fully justified.

Compared with amoebic infection, the prevalence of scuticociliatosis was found to be low (7-13\%). No outbreaks of disease or mortality were ever recorded, even when scuticociliatidia was present in turbot raised in the same water system, leading to serious outbreaks of disease and mortalities in that species. This suggests that sea bass is far more resistant than turbot to such infections, and if this is the case, the former fish may be a good farming alternative when scuticociliatidia is present.
\end{abstract}

(c) 2010 Elsevier B.V. All rights reserved.

\section{Introduction}

The European sea bass, Dicentrarchus labrax (Linnaeus, 1758), is a popular fish species in the European aquaculture industry. In fact, the aquaculture production of this fish species has been gradually increasing in Europe over the past 25 years (Haffray et al., 2007). The success of such an activity is, however, highly dependent on the medium

\footnotetext{
* Corresponding author at: Departamento de Biologia, Faculdade de Ciências, Universidade do Porto, Rua do Campo Alegre, s/n, FC4, 4169-007 Porto, Portugal. Tel.: +351 220402 805; fax: +351 220402709 .

E-mail address: mjsantos@fc.up.pt (M.J. Santos).
}

and available facilities, and also on the effective control of parasitic infections, all of which are of major concern to fish farmers.

To date, several parasitological surveys recording a very diverse parasitofauna have been conducted on sea bass from different marine environments (Giavenni, 1988; González-Lanza et al., 1991; Alvarez-Pellitero and Sitjà-Bobadilla, 1993; Alvarez-Pellitero et al., 1993; SitjáBobadilla and Alvarez-Pellitero, 1993; Santos, 1996, 1998; Caillot et al., 1999; Čož-Rakovac et al., 2002; Sterud, 2002; Candoso, 2004; Fioravanti et al., 2004, 2006). Unfortunately, none of these studies paid any attention to amoebic infections, and only Sterud (2002) referred the occurrence of a scuticociliatidia infection in wild sea bass. The for- 
Table 1

Environmental parameters (salinity, water temperature and $\mathrm{pH}$ ), sampling dates and fish data (length, weight, condition factor and age) (mean \pm standard deviation) from two fish farms (farms A and B) during the year.

\begin{tabular}{|c|c|c|c|c|c|c|c|c|}
\hline & \multicolumn{4}{|l|}{ Farm A } & \multicolumn{4}{|l|}{ Farm B } \\
\hline & Winter & Spring & Summer & Autumn & Winter & Spring & Summer & Autumn \\
\hline \multicolumn{9}{|l|}{ Environmental parameters } \\
\hline $\mathrm{pH}$ & 6 & 6 & 7 & 6 & 7 & 6 & 7 & 6 \\
\hline Temperature $\left({ }^{\circ} \mathrm{C}\right)$ & 11.5 & 13.0 & 16.0 & 16.0 & 13.0 & 20.5 & 18.6 & 13.0 \\
\hline Salinity (ppm) & 32 & 32 & 34 & 38 & 30 & 31 & 37 & 30 \\
\hline \multicolumn{9}{|l|}{ Fish data } \\
\hline Weight $($ mean \pm SD) $(\mathrm{g})$ & $214.5 \pm 36.6$ & $283.1 \pm 82.1$ & $271.6 \pm 52.6$ & $302.7 \pm 83.7$ & $28.4 \pm 5.7$ & $31.5 \pm 6.1$ & $12.5 \pm 2.5$ & $22.7 \pm 6.4$ \\
\hline Length $($ mean $\pm S D)(\mathrm{cm})$ & $26.3 \pm 1.5$ & $27.9 \pm 2.5$ & $28.2 \pm 1.8$ & $30.0 \pm 2.9$ & $14.2 \pm 0.8$ & $14.5 \pm 0.8$ & $10.5 \pm 0.7$ & $12.3 \pm 0.9$ \\
\hline $\begin{array}{l}\text { Condition factor }(\text { mean } \pm \text { SD) } \\
\left(\mathrm{g} / \mathrm{cm}^{3}\right)\end{array}$ & $0.73 \pm 0.06$ & $0.78 \pm 0.08$ & $0.75 \pm 0.05$ & $0.67 \pm 0.08$ & $0.61 \pm 0.07$ & $0.64 \pm 0.06$ & $0.68 \pm 0.09$ & $0.75 \pm 0.08$ \\
\hline Age & $2+$ & $2+$ & $3+$ & $3+$ & $0+$ & $0+$ & $0+$ & $0+$ \\
\hline$n$ & 28 & 30 & 31 & 28 & 30 & 30 & 30 & 30 \\
\hline Sampling date (2004) & 25 February & 03 May & 06 July & 26 October & $21 \mathrm{March}$ & 25 May & 22 September & 11 November \\
\hline
\end{tabular}

mer may be responsible for amoebic gill disease (AGD) (Dragesco et al., 1995; Dyková et al., 2000) and the latter for scuticociliatosis (Iglesias et al., 2001). These were also recently considered emergent diseases in other fish species (Dyková et al., 1998; Sterud et al., 2000; Nowak et al., 2002; Paramá et al., 2003, 2006; Alvarez-Pellitero et al., 2004; Kim et al., 2004; Puig et al., 2007; Rossteuscher et al., 2008). Indeed, they have been reported as the potential cause of severe disease outbreaks, which invariably lead to significant losses in fish farming systems.

The pathology associated with AGD can be easily detected in gross signs via the identification of slightly raised and white mucous patches on the gills (Adams and Nowak, 2001). Nevertheless, its aetiology must be confirmed by different observation techniques, namely the examination of wet mounts, hanging drop preparations, stained preparations, and mainly histological examination (Dyková and Novoa, 2001). Through histology, one can detect the initial phases of infection, which, most of the times, does not evidence gross signs. According to available literature (Dyková et al., 1995; Dyková and Novoa, 2001; Adams and Nowak, 2003, 2004; Adams et al., 2004; Taylor et al., 2009), AGD starts with necrosis of surface epithelial cells, due to the attachment of multiplying amoeba. This is then followed by hypertrophy and hyperplasia of cells adjacent to individual amoeba (leading to fusion of secondary lamellae), which ends up with oedema and the formation of cavities, also called interlamellar vesicles.

Although AGD has been mainly attributed to the infection by Neoparamoeba sp. (Adams and Nowak, 2004), other epizootic gill amoebae were also reported as agents of this fish disease (Dyková et al., 1999). Furthermore, accompanying the primary agent of AGD, histophagous ciliates, namely, Scuticocilates, were also found profiting from the AGD lesions (Dyková and Novoa, 2001).

The main goal of this study was to survey those potential agents in fish farms where it was expected to find infected sea bass. For achieving a wider application of the conclusions, two different fish farms were selected, one using salt water and the other brackish water. In one of the farms it was a priori known that sea bass were exposed to scuticociliatosis (since it had already been detected in turbot, Scophthalmus maximus L. (Ramos et al., 2006)). According to a previous parasitological survey (Candoso, 2003, personal communication), it was also suspected that amoeba was present in sea bass of the other fish farm. In addition, we intended to identify the seasons in which serious disease problems could occur, and to evaluate the effects of both of these parasitosis on the condition factor of European sea bass.

\section{Materials and methods}

To guarantee the detection of any possible infection in sea bass, and also to identify any potential seasonal behaviour, a parasitological survey for amoeba and scuticociliatidia was undertaken in 237 European sea bass, $D$. labrax, collected during one year - between the winter and autumn of 2004 - from two Portuguese fish farms. Furthermore, to enable a comparative study of sea bass condition factor with respect to the level of exposure to infection, two different fish farms were selected. One is an intensive fish farm using salt water, herein named farm A. It was known to have scuticociliatosis problems, as these had been previously detected in turbot (Ramos et al., 2006). The other is a semi-intensive fish farm using brackish water - identified as farm B - that was free of this scuticociliatosis problem, but was suspected of harbouring amoeba. Both fish farms were equipped with concrete tanks for keeping the fish, which were fed on a commercial fish diet. The water system of farm A is such that the water filling the sea bass tank comes directly from the contaminated turbot tanks.

Samples of about 30 fish were collected seasonally at each of the studied fish farms. In addition, since occurrence of parasites is known to vary with the environmental conditions, a sample of water was also collected from the concrete tanks on the collecting date. The environmental parameters of the water were selected according to their expected influence on the study: (1) $\mathrm{pH}$; (2) temperature $\left({ }^{\circ} \mathrm{C}\right)$; and $(3)$ salinity (ppm) (Table 1$)$.

When examined for parasites, all of the fish were also weighed, measured, aged and their condition factor determined (the latter is defined, according to Bagenal (1978), as the ratio between fish weight ' $W$ ' (in g) and the cube of fish length ' $\mathrm{L}^{3}$ ' (in $\mathrm{cm}^{3}$ ) multiplied by the constant value of 62.43) (Table 1).

All 117 fish collected at farm A belonged to the same fish stock (originated from an intensive aquaculture site in the 

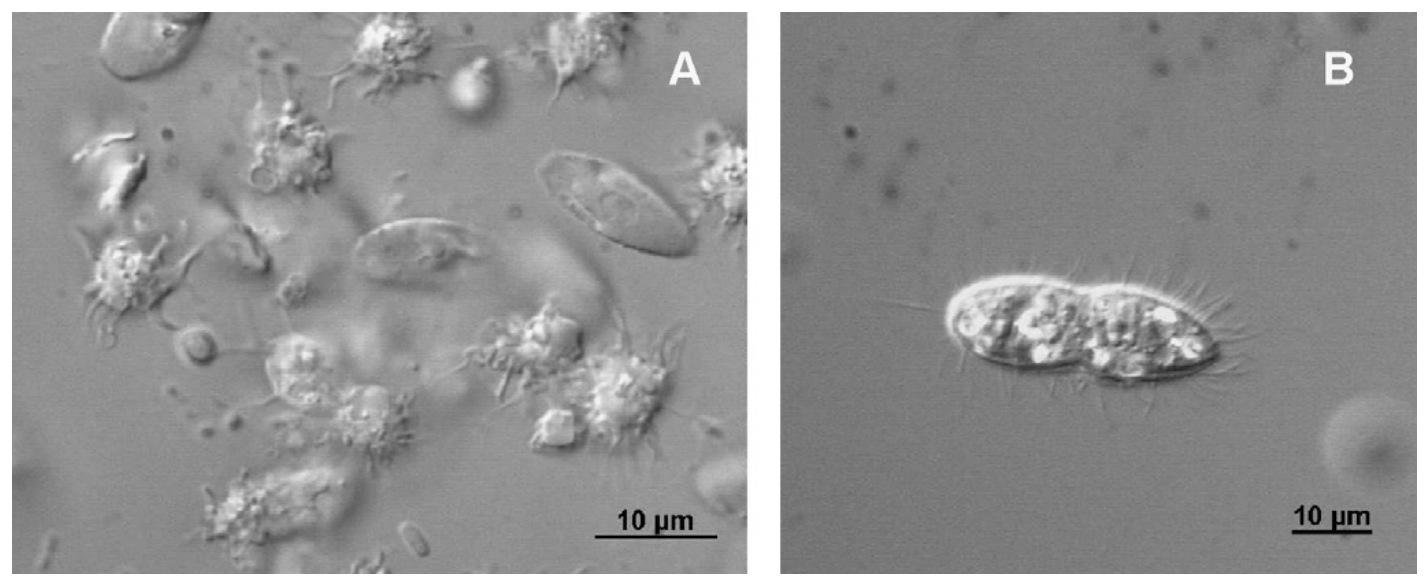

Fig. 1. Amoeba (A) and scuticociliatidia (B) from sea bass (D. labrax L.) gills.

South of France) and had already been in the fish farm for two years. The 120 fish from farm B belonged to two different stocks. The first two collected samples, i.e., winter and spring, belonged to the first stock, whilst the remaining two samples, i.e., summer and autumn, belonged to the second stock. When we took the first sample of both stocks, the fish had just arrived at the farm a few days before, coming from an intensive aquaculture site in Southern Portugal.

The parasitological survey of scuticociliatidia and amoeba was initially carried out macroscopically, and then using a compound microscope. The following organs were considered for analysis: (1) gills; (2) muscle; (3) posterior intestine; and (4) brain. They were chosen as they are main tissues infected by amoebae (1) (Dragesco et al., 1995; Dyková et al., 2000) and scuticociliatidia (2, 3, 4) (Iglesias et al., 2001). When the gills were fresh, a small portion was excised and centrifuged in water at $800 \mathrm{rpm}$. Subsequently, a drop of the pellet was kept in humid conditions for $30 \mathrm{~min}$ and observed on hanging drop slides. This procedure was intended to concentrate any amoebae that might be present. The protozoans recovered were identified according to Lee et al. (2000).

Histological samples of brain, gills, muscle and the posterior intestine were washed and fixed in Davidson's saline solution, which were later replaced with $70 \%$ ethanol for storage. However, histological examination was only carried out when fresh analyses detected high parasite intensities (i.e., more than 10 individuals per 10 microscope fields at $400 \times$ magnification).

In assessing infection levels, prevalence was determined, according to Bush et al. (1997), for each season of the year (seasonal prevalence) and for each farm (total prevalence).

To detect any possible relation between parasites and host, even in the presence of only a silent infection, a comparison of host condition factor, fish length and fish weight was performed between the infected and uninfected fish for each parasitosis, in each sample (season) and in each farm. The comparison was conducted using a Student's $t-$ test or, alternatively, a Mann-Whitney $U$-test when the parametric requisites were not met, both with $p<0.05$. The software used for this statistical analysis was SPSS 16.0 (SPSS Inc, 2007).

\section{Results}

With respect to recorded environmental parameters, i.e., water $\mathrm{pH}$, temperature and salinity, some differences were noted between the sampled farms (Table 1). On most instances, the water of farm A presented higher salinities (32-38 ppm) and lower temperatures $\left(11.5-16^{\circ} \mathrm{C}\right)$ than those of farm $\mathrm{B}$. The $\mathrm{pH}$ remained fairly constant (at about 7) throughout the entire year for both sampled farms. These results were expected given the nature of the water supplies of the studied fish farms (salt and brackish water, respectively).

No disease outbreaks or mortality were noticed in sea bass in any season of the year, or in any of the farms.

Macroscopic analysis of the fish gills, muscle, posterior intestine and brain, did not reveal any kind of abnormality or other symptoms indicative of serious parasitic infection. However, at the microscopic level, parasites were found infecting the gills: Amoeba (Rhizopoda von Siebold, 1845) and Scuticociliatidia Small, 1967 (Fig. 1 (A and B)).

As shown in Fig. 2, amoebae were common parasites with a recorded total prevalence greater than $43 \%$. Scuticociliatidia was comparatively less prevalent, with values

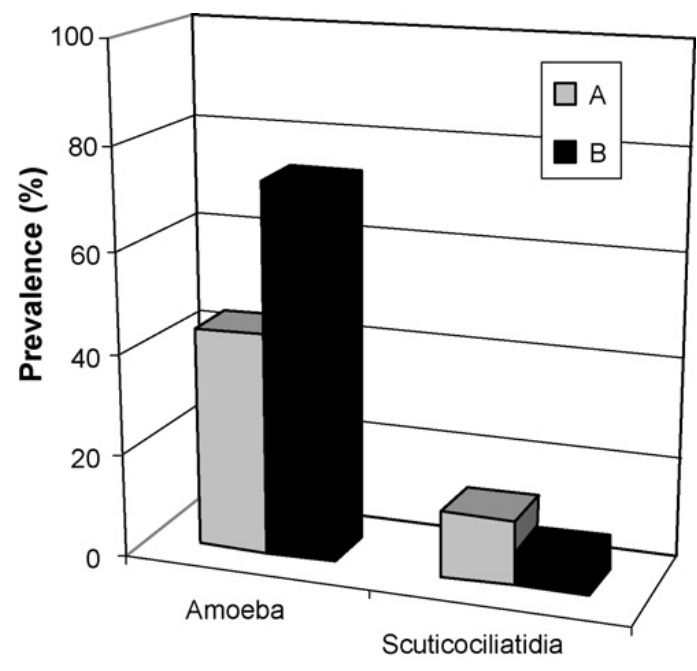

Fig. 2. Total prevalence of amoeba and scuticociliatidia in sea bass ( $D$. labrax L.) from two fish farms (farms A and B). 


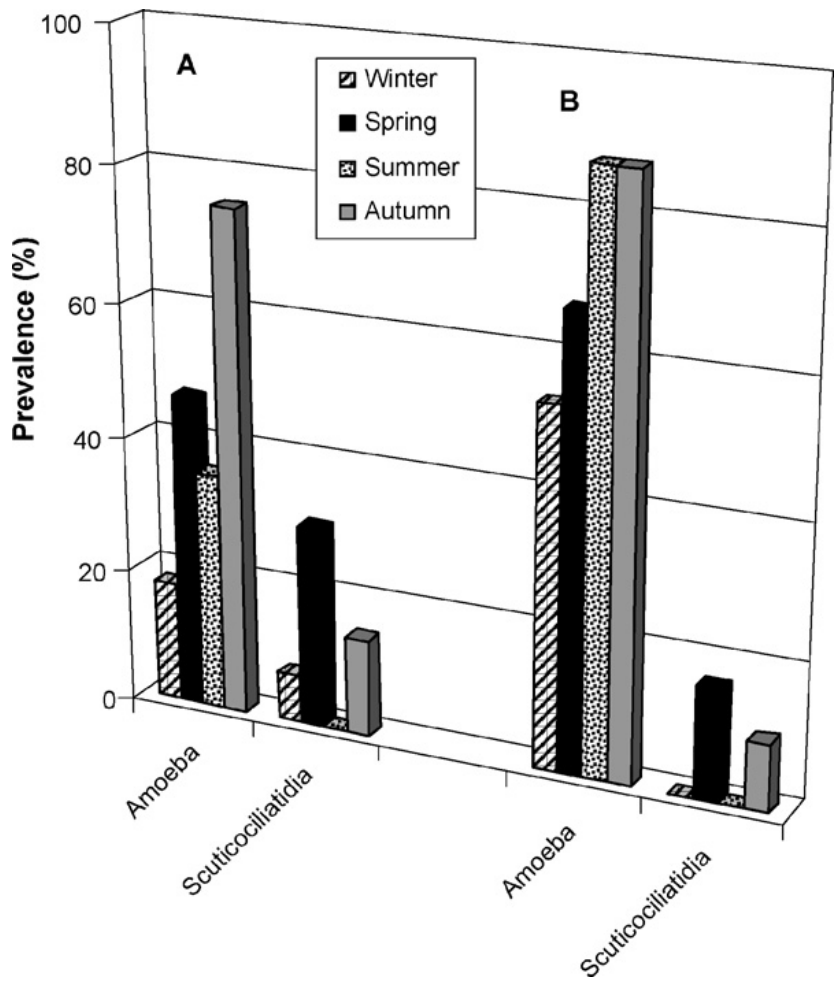

Fig. 3. Temporal variation in prevalence of amoeba and scuticociliatidia from sea bass (D. labrax L.) from farms A and B.

of total prevalence less than $13 \%$. Comparative analyses of the recorded parasites have shown that both parasites were common to both groups of sampled fish from farms A and B.

With respect to the fish sampled at farm $A$, the main results for different seasons were as follows (Fig. 3): gill amoebae were more prevalent in autumn (75\%), whereas during the remaining seasons of the year (particularly winter) comparatively lower prevalence values (17.9-46.7\%) were reported, and scuticociliatidia infections were mainly present in spring (30\%).

As far as the fish of farm B are concerned, the temporal variations were as follows (Fig. 3): the seasonal prevalence of gill amoebae exhibited higher values during summer and autumn, with levels always greater than $53 \%$; and the seasonality of scuticociliatidia infections was similar to that recorded for farm $\mathrm{A}$, with greater prevalence levels found during the spring (16.7\%), and with no records observed during the first season of sampling for either stock of fish. This permits us to conclude that the later infection, first noted in the second sample, may have started when the fish were already in the farm.

As indicated above, none of the examined fish exhibited macroscopic lesions, external or internal, resulting from parasitic infections. However, in farm B, the fish more heavily infected with gill amoebae presented typical AGD histopathological signs, i.e., hyperplasia, secondary lamellae fusion and cavity formation (interlamellar vesicles), as depicted in Fig. 4. The hyperplasic tissue, in particular the interlamellar vesicles, were filled with hypertrophied host cells and amoeba, as shown in Fig. 4(C). Histological observations were also conducted for scuticociliatidia infection. However, no evidence was found of any histopathological effects of this parasitosis in sea bass.
The analyses of host condition factor in each sample (i.e., for each season), a measure of fish fitness, showed no significant differences among infected and uninfected fish of the two farms, both for amoeba (M-W Utest $=42.5-101.5, W=273.5-167.5$, with $p=0.10-0.73)$ and scuticociliatida $(\mathrm{M}-\mathrm{W} U$-test $=22.0-61.5, W=373.0-386.5$, with $p=0.72-0.96)$. Therefore, a combined analysis of the host condition factor of the total sample (i.e., for of each farm) was conducted.

For farm A, the analyses of host condition factor, with respect to the amoeba infection, showed mean values ( \pm standard deviation) of $0.72( \pm 0.08)$ and $0.75( \pm 0.08)$, for infected $(n=51)$ and uninfected $(n=64)$ fish, respectively. The statistical analysis revealed significant differences between these fish groups ( $t$-test $t=-2.54$, with $p=0.01$ ). On what scuticociliatidia infection is concerned, the host condition factor mean values ( \pm standard deviation) were $0.74( \pm 0.07)$ and $0.73( \pm 0.08)$, for infected $(n=15)$ and uninfected $(n=100)$ fish, exhibiting no statistically significant differences ( $t$-test $t=0.80$, with $p=0.76$ ).

For farm B, host condition factor did not meet all of the parametric requisites. So, a Mann-Whitney $U$-test had to be used instead of the $t$-test. Regarding the amoeba infection, the mean values (range) of fish condition factor were 0.68 (0.54-0.93) and $0.61(0.51-0.78)$, for the infected $(n=88)$ and uninfected $(n=32)$ fish, respectively. Although, the host condition factor mean value of infected fish was higher than the one of the uninfected, these values were considered significantly different $(\mathrm{M}-\mathrm{W} U$-test $=649, W=1177$, with $p=0.00$ ).

In order to correctly interpret this unexpected result, we also compared the absolute values of fish length and weight for infected versus uninfected fish. We recorded a mean value of $12.6( \pm 1.9) \mathrm{cm}$ and $13.6( \pm 1.5) \mathrm{cm}$ for the length of infected and uninfected fish, respectively, which showed significant differences ( $t$-test $t=2.83$, with $p=0.01$ ). Nevertheless, the weight mean values were $23.2( \pm 9.5) \mathrm{g}$ and 25.3 $( \pm 7.4) \mathrm{g}$, respectively, which did not show any statistically significant differences ( $t$-test $t=1.01$, with $p=0.21$ ). These data suggest that fish development, measured by length, is, indeed, affected by the infection. However, since the condition factor is linearly dependent on the weight and inversely proportional to the cube of the length, being thus highly sensitive to fish length variations, even the smallest decrements of length growth in young fish may cause abnormal increments of host condition factors.

Still evaluating fish condition factor from farm B, but now with respect to scuticociliatidia infection (and considering only the second sample of both stocks, because no infection was recorded in the first sample), the mean values (range) of fish condition factor in infected $(n=8)$ versus uninfected fish $(n=52)$ were $0.67(0.54-0.77)$ and 0.69 (0.54-0.92), respectively. These do not reveal any statistically significant differences $(M-W U$-test $=164, W=200$, with $p=0.35$ ).

\section{Discussion and conclusions}

The first worth noting result is that branchial amoebae and scuticociliatidia were studied for the first time from sea bass in Portuguese waters. Moreover, prevalence levels 

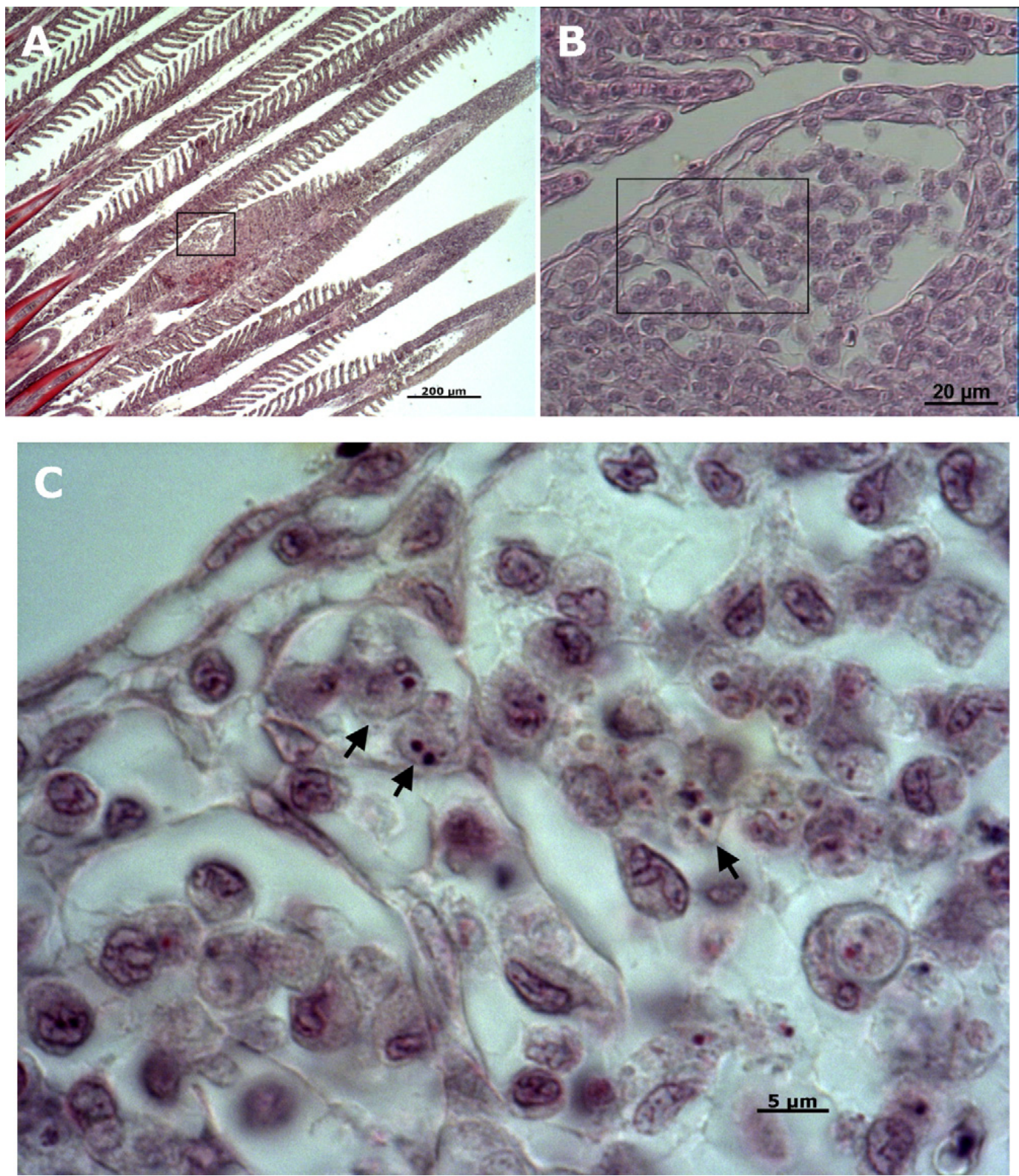

Fig. 4. Gills histology of sea bass (D. labrax L.) with pathological signs of amoebic gill disease infection. (A) Hyperplasia, secondary lamellae fusion and interlamellar vesicles. (B) A magnification of a large interlamellar vesicle (identified in A). (C) A further magnification of the infected tissue (identified in B) where hypertrophied host cells and amoebae (arrows) are visible.

were found to be high for amoebae and low for scuticociliatidia, regarding both their seasonal and total values.

Gill amoebae are regarded as euryhaline organisms, with water temperature being more important than salinity in determining the occurrence of disease outbreaks (Paniagua et al., 1998). However, freshwater baths are considered as an important way of combating such parasitosis (Munday et al., 2001). In the present work, prevalence levels for gill amoebae were found to be higher for fish from brackish water than from seawater. Such a situation might suggest that, in brackish water, temperature is more favourable for amoebal development and survival, and that the salinity level was never sufficiently low to eliminate the parasite. Furthermore, AGD histopathology was observed (with occurrence of amoeba in infected tissues), even in cases where no macroscopic lesions were detected. However, this infection did affect host condition factor in farm
A and was recorded as delaying fish growth in farm B. In conclusion, despite no disease outbreaks or mortality were reported, the observed histopathology signs that impacted the host condition factor or the growth rate, constitute a significant issue for the fish farm owners, which advise the implementation of measures for controlling this infection. In this respect, we suggest that a freshwater bath may be considered as a recommended routine treatment to avoid this infection.

Scuticociliatidia outbreaks leading to death were reported for turbot (Scophthalmus maximus L.) stocks raised on farm A during the period of this study (Ramos et al., 2006). Although such outbreaks in turbot have been recorded during all seasons of the year, higher infection levels were found on May, July and August, i.e., at the end of the spring and summer seasons. As verified for the sea bass examined in this study, the peak the prevalence of scu- 
ticociliatidia also occurred during the spring. It is therefore reasonable to believe that, considering the source of the running water, i.e., from the contaminated turbot tanks into the sea bass tanks, turbot stocks may have acted as some kind of 'contamination source' to the sea bass. Conversely, during summer, sea bass infection with scuticociliatidia in farm A was found to be very low. This was unexpected, since the outbreaks in turbot were still continuing. This seems to be a result of the higher level of immunocompetence of the sea bass to this infection, probably determined by the higher water temperatures recorded for that season. For this infection, host condition factor was not significantly affected by the presence of the parasite. In fact, it is suggested that sea bass is far more resistant to the presence of this parasite, at least in comparison with turbot. Due to the serious problems caused by scuticociliatidia, the exploitation of a more resistant fish might be necessary, and sea bass may be a good candidate for this role. Nevertheless, further experiments, with controlled environmental conditions, must be performed to confirm this important issue.

As a final conclusion, we can say that both amoebae and scuticociliatidia infections are present, and maybe more widely distributed than what has been reported in sea bass, even if disease outbreaks are absent and thus the infections can be virtually unnoticed. Moreover, special care should be taken with the amoeba infection, since its presence may cause serious pathology. On the other hand, all sea bass seamed to be particularly resistant to scuticociliatidia infections.

\section{Acknowledgements}

We would like to thank: the University of Porto, Fundação Ilídio Pinho (Undergraduate Research Programme, 2004), the Faculty of Sciences and the CIIMAR/CIMAR Ass. Lab. for funding this work; D. Gibson for reading the manuscript; A. Saraiva to her help with the work methodology and bibliography; L. Cancela, R. Maia, I. Alves and F. Coutinho for helping with observations; and the fish farm owners by offering us the sea bass.

\section{References}

Adams, M.B., Nowak, B.F., 2001. Distribution and structure of lesions in the gills of Atlantic salmon, Salmo salar L., affected with amoebic gill disease. J. Fish Dis. 24, 535-542.

Adams, M.B., Nowak, B.F., 2003. Amoebic gill disease: sequential pathology in cultured Atlantic salmon, Salmo salar L. J. Fish Dis. 26, 601-614.

Adams, M.B., Nowak, B.F., 2004. Experimental amoebic gill disease of Atlantic salmon, Salmo salar L.: further evidence for the primary pathogenic role of Neoparamoeba sp. J. Fish Dis. 27, 105-113.

Adams, M.B., Ellard, K., Nowak, B.F., 2004. Gross pathology and its relationship with histopathology of amoebic gill disease (AGD) in farmed Atlantic salmon, Salmo salar L. J. Fish Dis. 27, 151-161.

Alvarez-Pellitero, P., Sitjà-Bobadilla, A., 1993. Ceratomyxa spp. (Protozoa: Myxosporea) infections in wild and cultured sea bass, Dicentrarchus labrax, from the Spanish Mediterranean area. J. Fish. Biol. 42, 889-901.

Alvarez-Pellitero, P., Sitjà-Bobadilla, A., Franco-Sierra, A., 1993. Protozoan parasites of wild and cultured sea bass, Dicentrarchus labrax (L.), from the Mediterranean area. Aquat. Fish. Manage. 24, 101-108.

Alvarez-Pellitero, P., Palenzuela, O., Padrós, F., Sitjà-Bobadilla, A., Riaza, A., Silva, R., Arán, J., 2004. Histophagous scuticociliatids (Ciliophora) parasitizing turbot Scophthalmus maximus: morphology, in vitro culture and virulence. Folia Parasitol. 51, 177-187.
Bagenal, T., 1978. Methods for assessment of fish production in freshwater. I.B.P. Handbook, vol. 3., 3rd ed. Blackwell Scientific Publications Oxford, London.

Bush, A., Lafferty, K., Lotz, J., Shostak, A., 1997. Parasitology meets ecology on its own terms: Margolis et al. revisited. J. Parasitol. 83, 575-583.

Caillot, C. Morand, S., Muller-Graf, C.M., Faliex, E., Marchand, B., 1999. Parasites of Dicentrarchus labrax, Anguilla anguilla and Mugil cephalus from a pond in Corsica, France. J. Helminthol. Soc. Washington 66 95-98.

Candoso, M., 2004. Seasonal variation of the main parasitosis of aquaculture sea bass (Dicentrarchus labrax L.) from the Aveiro's Estuary. M.Sc Dissertation. University of Porto Faculty of Sciences, Porto, Portugal (in Portuguese with English summary).

Čož-Rakovac, R., Strunjak-Perović, I., Topić Popović, N., Hacmanjek, M., Šimpraga, B., Teskeredžić, E., 2002. Health status of wild and cultured sea bass in the northern Adriatic Sea. Vet. Med. Czech 47, 222 226.

Dragesco, A., Dragesco, J., Coste, F., Gasc, C., Romestand, B., Raymond, J.C., Bouix, G., 1995. Philasterides dicentrarchi, n. sp. (Ciliophora, Scuticociliatidia), a histophagous opportunistic parasite of Dicentrarchus labrax (Linnaeus, 1758), a reared marine fish. Eur. J. Protistol. 31, 327-340.

Dyková, I., Novoa, B., 2001. Comments on diagnosis of amoebic gill disease (AGD) in turbot, Scophthalmus maximus. Bull. Eur. Assoc. Fish Pathol. $21,40-44$.

Dyková, I., Figueras, A., Novoa, B., 1995. Amoebic gill infection of turbot, Scophthalmus maximus. Folia Parasitol. 42, 91-96.

Dyková, I., Figueras, A., Novoa, B., Casal, J.F., 1998. Paramoeba sp., an agent of amoebic gill disease of turbot Scophthalmus maximus. Dis. Aquat. Organ. 33, 137-141.

Dyková, I., Figueras, A., Novoa, B., 1999. Epizoic amoebae from the gills of turbot Scophthalmus maximus. Dis. Aquat. Organ. 38, 33-38.

Dyková, I., Figueras, A., Peric, Z., 2000. Neoparamoeba page, 1987: light and electron microscopic observations on six strains of different origin. Dis. Aquat. Organ. 43, 217-223.

Fioravanti, M.L., Caffara, M., Florio, D., Gustinelli, A., Marcer, F., 2004 Sphaerospora dicentrarchi and S. testicularis (Myxozoa: Sphaerosporidae) in farmed European sea bass. Folia Parasitol. 51, 208-210.

Fioravanti, M.L., Caffara, M., Florio, D., Gustinelli, A., Marcer, F., 2006. A parasitological survey of European sea bass (Dicentrarchus labrax) and gilthead sea bream (Sparus aurata) cultured in Italy. Vet. Res. Commun. 30 (Suppl. 1), 249-252.

Giavenni, R., 1988. Some parasitic and other diseases occurring in seabass (Dicentrarchus labrax L.) broodstocks in Italy. Bull. Eur. Assoc. Fish. Pathol. 8, 45-46.

González-Lanza, C., Alvarez-Pelliteiro, M.P., Sitjá-Bobadilla, A., 1991. Diplectanidae (Monogenea) infestations of sea bass, Dicentrarchus labrax (L.), from the Spanish Mediterranean area. Histopathology and population dynamics under culture conditions. Parasitol. Res. 77, 307-314.

Haffray, P., Tsigenopoulos, C.S., Bonhomme, F., Chatain, B., Magoulas, A., Rye, M., Triantafyllidis, A., Triantaphyllidis, C., 2007. Genetic effects of domestication, culture and breeding of fish and shellfish, and their impacts on wild populations. European sea bass - Dicentrarchus labrax. pp. 40-46, In: Svåsand, T., Crosetti, D., García-Vázquez, E., Verspoor, E. (eds). Genetic impact of aquaculture activities on native populations. Genimpact Final Scientific Report (EU contract no. RICA-CT-2005022802), http://genimpact. imr.no/.

Iglesias, R., Paranamá, A., Alvarez, M.F., Leiro, J., Fernández, J., Sanmartín, M.L., 2001. Philasterides dicentrarchi (Ciliophora, Scuticociliatidia) as the causative agent of scuticociliatosis in farmed turbot Scophthalmus maximus in Galicia (NW Spain). Dis. Aquat. Organ. 46, 47-55.

Kim, S.M., Cho, J.B., Kim, S.K., Nam, Y.K., Kim, K.H., 2004. Occurrence of scuticociliatosis in olive flounder Paralichthys olivaceus by Philasterides dicentrarchi (Ciliophora: Scuticociliatida). Dis. Aquat. Organ. 62, 233-238.

Lee, J.J., Leedale, G.F., Bradbury, P. (Eds.), 2000. In: Organisms Traditionally Referred to as Protozoa, or Newly Discovered Groups, vols. I and II, 2nd ed. Society of Protozoologists, Lawrence, KS, USA.

Munday, B.L., Zilberg, D., Findlay, V., 2001. Gill disease of marine fish caused by infection with Neoparamoeba pemaquidensis. J. Fish Dis. 24, 497-507.

Nowak, B.F., Carson, J., Powell, M.D., Dyková, I., 2002. Amoebic gill disease in the marine environment. Bull. Eur. Assoc. Fish. Pathol. 22, 144-147.

Paniagua, E., Fernández, J., Ortega, M., Paramá, A., Sanmartín, M.L., Leiro, J., 1998. Effects of temperature, salinity and incubation time on in vitro survival of an amoeba infecting the gills of turbot, Scophthalmus maximus L. J. Fish Dis. 21, 77-80.

Paramá, A., Iglesias, R., Álvarez, M.F., Leiro, J., Aja, C., Sanmartín, M.L., 2003. Philasterides dicentrachi (Ciliophora, Scuticociliatidia) experimenta 
infection and possible routes of entry in farmed turbot (Scophthalmus maximus). Aquaculture 217, 73-80.

Paramá, A., Arranz, J.A., Alvarez, M.F., Sanmartín, M.L., Leiro, J., 2006. Ultrastructure and phylogeny of Philasterides dicentrarchi (Ciliophora, Scuticociliatia) from farmed turbot in NW Spain. Parasitology 132, 555-564.

Puig, L., Traveset, R., Palenzuela, O., Padrós, F., 2007. Histopathology of experimental scuticociliatosis in turbot Scophthalmus maximus. Dis. Aquat. Organ. 76, 131-140.

Ramos, M.F., Costa, A.R., Barandela, T., Saraiva, A., Rodrigues, P.N., 2006. Scuticociliate infection and pathology in cultured turbot Scophthalmus maximus from the north of Portugal. Dis. Aquat. Organ. 74, 249-253.

Rossteuscher, S., Wenker, C., Jermann, T., Wahli, T., Oldenberg, E., SchmidtPosthaus, H., 2008. Severe scuticociliate (Philasterides dicentrarchi) infection in a population of sea dragons (Phycodurus eques and Phyllopteryx taeniolatus). Vet. Pathol. 45, 546-550.

Santos, M.J., 1996. Observations on the parasitofauna of wild sea bass (Dicentrarchus labrax L.) from Portugal. Bull. Eur. Assoc. Fish. Pathol. 16, 77-79.
Santos, M.J., 1998. Parasites of sea bass (Dicentrarchus labrax L.) from the Aveiro's Estuary and its population dynamic. Ph.D. Thesis. University of Porto Faculty of Sciences, Porto, Portugal (in Portuguese with English summary).

Sitjá-Bobadilla, A., Alvarez-Pellitero, P., 1993. Population dynamics of Sphaerospora dicentrarchi Sitjá-Bobadilla, A. and Alvarez-Pellitero, P. (1992) and S. testicularis Sitjá-Bobadilla, A. and Alvarez-Pellitero, P., 1990 (Myxosporea: Bivalvulida) infections in wild and cultured Mediterranean sea bass (Dicentrarchus labrax L.). Parasitology 106, 39-46.

SPSS Inc, 2007. SPSS Base 16.0 User's Guide. Chicago, IL.

Sterud, E., 2002. Parasites of wild sea bass Dicentrarchus labrax from Norway. Dis. Aquat. Organ. 48, 209-212.

Sterud, E., Hansen, M.K., Mo, T.A., 2000. Systemic infection with Uronemalike ciliates in farmed turbot, Scophthalmus maximus (L.). J. Fish Dis. $23,33-37$.

Taylor, R.S., Muller, W.J., Cook, M.T., Kube, P.D., Elliott, N.G., 2009. Gill observations in Atlantic salmon (Salmo salar, L.) during repeated amoebic gill disease (AGD) field exposure and survival challenge. Aquaculture 290, 1-8. 